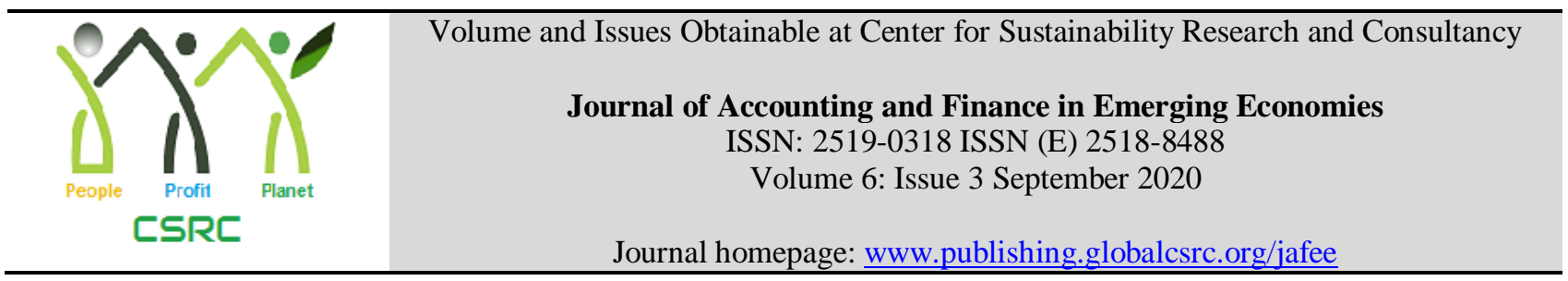

\title{
An Overview of the Necessities, Challenges \& Outcomes of Building Information Modeling (BIM) Framework Used in Project Management
}

\author{
${ }^{1}$ Shahid Iqbal, ${ }^{2}$ Muhammad Saad, ${ }^{3}$ Masab -Bin -Shahid, ${ }^{4}$ Wajeeha Batool \\ ${ }^{1}$ Assistant Professor, Management Studies Department,Bahria University, Islamabad Campus, Pakistan, \\ siqbal.buic@bahria.edu.pk \\ ${ }^{2}$ Deputy Manager (Coord.), Diamer Bhasha Dam Project,Islamabad, Pakistan, saad.fahad94@gmail.com \\ ${ }^{3}$ Police Communication Officer,Punjab Safe Cities Authority, Lahore, Pakistan, masababbasi87@gmail.com \\ ${ }^{4}$ Assistant Project Coordinator, Dev Arcade, Lahore, Pakistan, wajeehabatool5@gmail.com
}

\begin{abstract}
ARTICLE DETAILS
\end{abstract}
\section{History}

Revised format: August 2020

Available Online: September

2020

\section{Keywords}

Building Information Modeling,

Project Management,

Engineering Management,

Construction industry

\section{JEL Classification}

M1, M19

\section{ABSTRACT}

Building Information Modeling (BIM) is gaining attention worldwide due to its assistances during the entire building's construction life cycle covering all phases of project from commencement to accomplishment. BIM integrates different disciplines by effective communication, analyzes the project systems for constructability, estimates the cost and time of projects at any time using quantity takeoffs. Notwithstanding that fact Pakistan like other developing countries is lagging in Building Information Modeling (BIM) adoption. To facilitate the adoption of Building Information Modeling (BIM) in the AEC industry, the purpose of this research study is to identify the important factors for BIM adoption among construction engineers of Pakistan to carry out the awareness. It is found statistically that Building Information Modeling (BIM) capability is most important factors for the adoption of BIM among the construction engineers in Pakistan having the factors of motivation and management support which positively effect on BIM adoption in Pakistan. The trainings are very important to increase the BIM adoption in the industry.

\section{OPEN ACCESS}

(C) 2020 The authors, under a Creative Commons

Attribution-NonCommercial 4.0

Corresponding author's email address: siqbal.buic@ bahria.edu.pk

Recommended citation: Iqbak, S., Saad, M., Shahid, M. B. \& Batool, W. (2020). An overview of the Necessities, Challenges \& Outcomes of Building Information Modeling (BIM) Framework used in Project Management. Journal of Accounting and Finance in Emerging Economies, 6(3), 873-883

\section{Introduction}

Construction industry of Pakistan is rising day by day, the development rate of construction sector is 11.5 percent during the period of 2017-2018 while it was 9.05 percent during the period of 2016-2017 (Ali, 2018). Construction is the single sector in Pakistan that produces major employment. Similar many other countries in world, construction industry in Pakistan has not considerable record in terms of project completion within cost, schedule, and quality baselines. As the nature \& size of construction projects is growing, the stakeholder's prospects at advanced level. Due to flexibility of construction projects most of the information is required to communicate between project team members and important stakeholders at accurate time. Indecorous information flow among the stakeholder leads to the meager coordination which puts adverse impact on the performance such as on schedule, cost, quality of project 
(Ding, 2015).

Many research studies all over the world showed that use of technology (ICT) like BIM against traditional management approaches can increase the performance of construction projects. BIM has gained much consideration in Engineering \& Construction industry (Masood, 2014) due to its various purposes like more visualization (Adoption of Building Information Modelling, 2014), progress monitoring facility (Masood, 2014), Building performance prediction (Ding, 2015) and better communication between parties (Hatem, 2018). Engineers are the professionals that are one of the most vibrant contributors of BIM adoption in all over the world for the design purpose of buildings.

\section{Literature Review and Research Hypothesis \\ 2.1 Building Information Modeling (BIM) Meaning}

Building Information Modeling (BIM) is defined as "a digital representation of physical and functional characteristic of a facility" by National Institute of Building Science (NIBS, 2007). In 1970, first time concept of BIM is used by Chuck Eastman and Robert Aish (J, 2007). In the earlier times BIM was known by different names like virtual building, intelligent object and product model (Ozorhon, 2016). BIM is getting great attention of architects and project managers as BIM can be used for the planning, execution and operations for the project. In a nutshell BIM is not just software but a process (Azhar, 2011).

Building Information Modeling portrays the geometry, geographic special relationships, quantities and features of the building elements, material inventory management, cost and schedule performances (Bazianic, 2004). BIM role is just like a stage where you can easily share the knowledge and communicate without difficulty with the project stakeholders (Hergunsel, 2011). BIM is the software that accomplishes the function of producing and managing the data during the complete life cycle of the building. BIM is a new technology that can be functional to the design, construction management and facility management in which digital representation helps in exchanging necessary information between all project stakeholders.

While working at building project with BIM in progress, there is complexity of gathering related information, due to this some companies have developed software that work within the framework of BIM. This software is different from AutoCAD as they provide additional functional from drafting that are time, cost control and product specifications etc. Autodesk Revit is one of the greatest examples of BIM tool that software used not only by architects but also from structure engineers, mep engineers, designers and contractors as well (Latiffi, 2013).

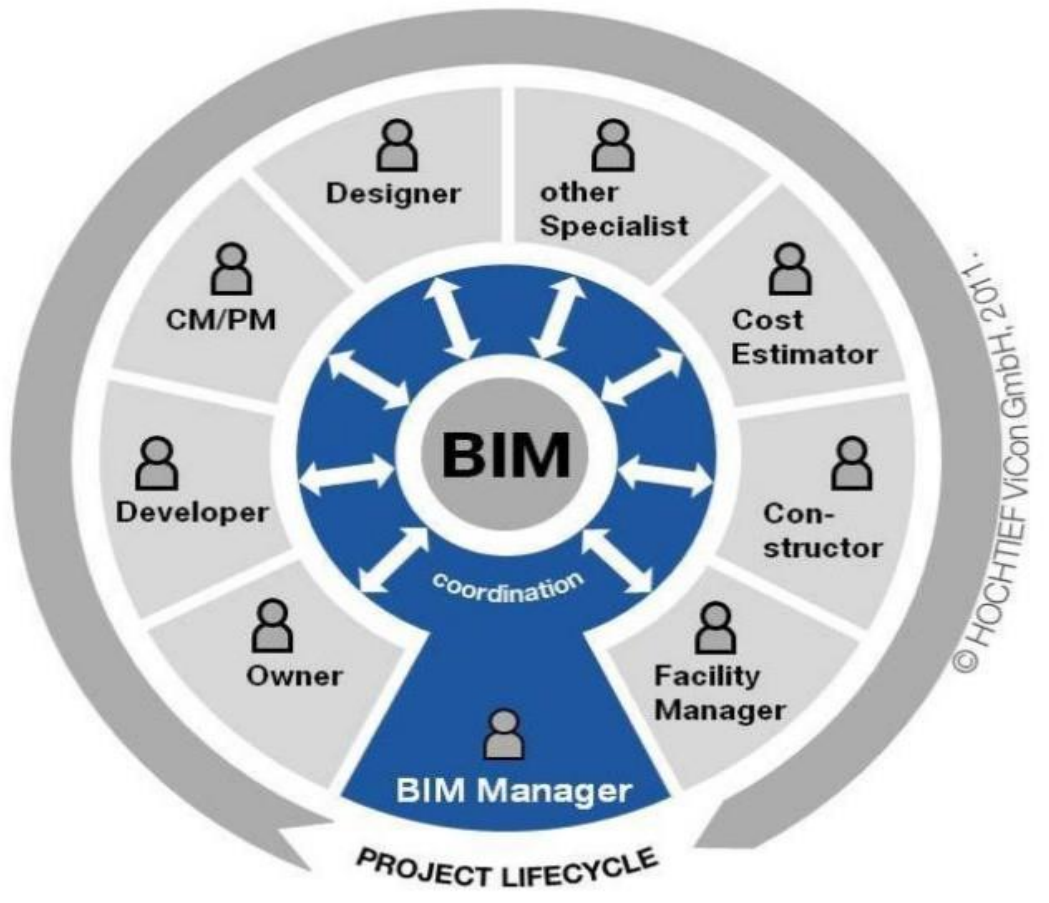

Fig 1: BIM Coordination in construction project management 


\subsection{Assistances of Building Information Modeling (BIM)}

Building Information Modeling (BIM) is one of the latest and most promising development in the construction industry (Hussain, 2013). BIM adoption is very convenient for the forecasting of building performance and operation (Azhar, 2011). In a research study conducted in 1997 by Mendelsohn it was established that more than $75 \%$ of the difficulties at site are directly/indirectly due to the flaws in the design, that are emphasized by execution team of the projects. These design flaws lead to the rework. In United Kingdom, BIM is obligatory for all the contractors to gain new government contracts. BIM can be used as a automobile for the communication between project stakeholders in a project environment (BIM Handbook) as Project management body of knowledge (PMBOK) gives communication a great importance. During the $50^{\text {th }}$ ASC Annual International Conference Proceeding, 18 design-phase functions of BIM relevant to architectures were identified included Clash recognition, Constructability, Building Drawings, Database Information Management, Design of multifaceted structures, Estimation, Facility management, Initial Presentation, Interior environmental analysis, LEED, Municipal code, Parametric design, Performance optimization, Site examination, maintenance and renovation, Sustainable design, value engineering and last but not the least visualization. The study additionally tells us that the most adopted function of BIM by architects is visualization and initial presentation. Visualization gives more strong vision about what the finishing product may look like (Hergunsel, 2011). BIM adoption deliver more control to project manager on variables such as reducing the cost, reducing the completion time and refining the quality of project during the all phases of the project. (Azhar S. , 2008). BIM acceptance also recovers the document management and integration as well (Fazli, 2014). BIM adoption provides support and facilitates in decision making process, increasing of financial control, squeeze down time in documentation, improves construction quality free of defects products and collaboration. (Mesároš, 2017).

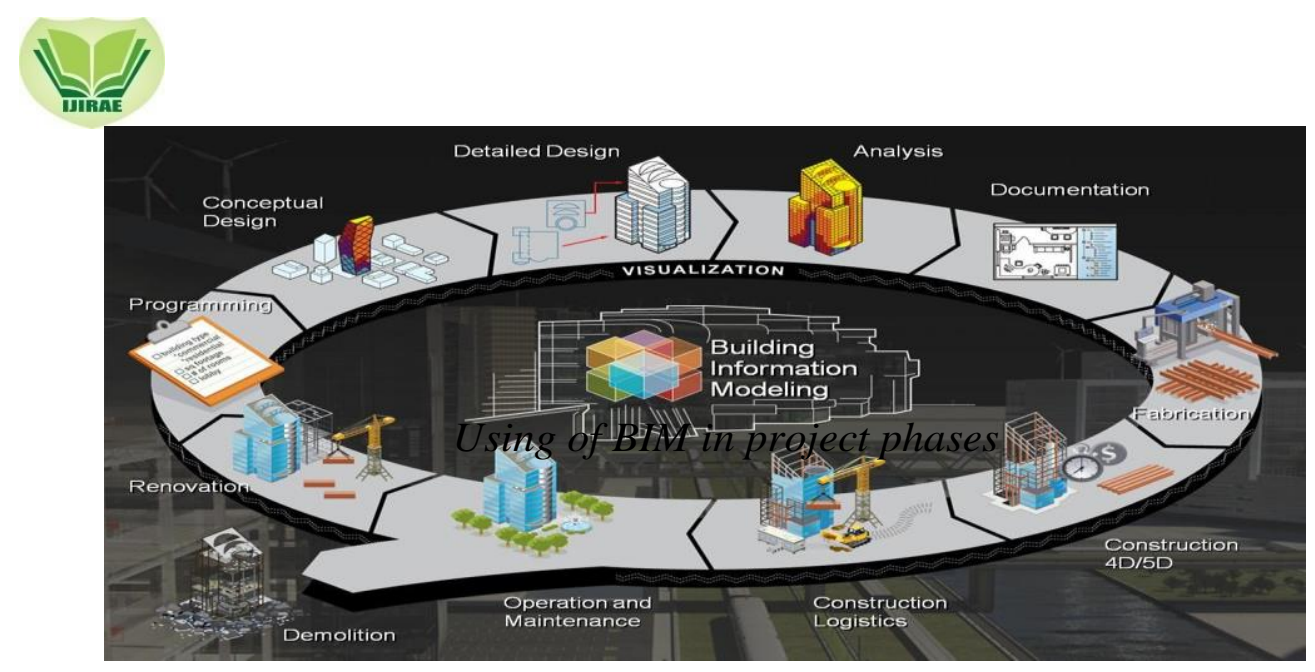

\subsection{Obstacles in Building Information Modeling (BIM) Adoption}

The significant barrier in BIM acceptance is the absence of engagement of other consultants Structural, MEP etc in the BIM procedure by engineers (Mankani, 2009). People in Pakistan are not ready to accept the variations so it's a big obstacle for adopting the novel and state-of-the-art technologies like BIM (Masood, 2014). BIM can have economy and interoperability issues (Hong, 2016). In a new research study conducted in India, attitude and cultural blockades were noted as main challenges in BIM adoption (RICS, 2014).

\subsection{Challenges Precarious Factors for Building Information Modeling (BIM) Adoption}

Many critical factors are identified for efficacious BIM acceptance in worldwide from researchers. In a recent study conducted in china, all the critical factors identified are divided in the five categories that are BIM capability, motivation, knowledge structure technical defects of BIM and management support (Ding, 2015).

\subsection{Building Information Modeling (BIM) Necessities \& Competence}

BIM capabilities like partnership, following and involvement of using BIM of a project team are most important to indorse BIM adoption (Mutai, 2009). In a project team, numerous persons have not elementary training of BIM to apply throughout the whole life cycle of the project. Meanwhile the beginning of BIM technology, education and training are trials for adopting BIM. Partnership between the disciplines is very critical for BIM adoption (Azhar, 
2011). The importance of BIM capability is also reflected by the rising demands of acquaintance to BIM for graduates from built environment related programs.

\subsection{Building Information Modeling (BIM) Motivation}

BIM Motivation is one of the foremost factors which is also considered as critical for the BIM acceptance. Motivation has two types; internal motivation and external motivation. Personal motivation mentions to extent to which an individual team member prepared for the usage of the new technologies for enhanced performance and productivity. Perceived usefulness is a concept that can be used under the umbrella of personal motivation; perceived usefulness a term that displays the degree to which an individual trusts that using a novel system will improve its performance (Hong, 2016).

External motivation notices the stimulus from participants or other stakeholders in the construction business. Customers even use BIM as a part of tendering and bidding processes, not only in public projects but also for private projects.

\subsection{Building Information Modeling (BIM) Management Support \& Outcomes}

A systematized and efficient management will offer employees' acceptable education and BIM competence which bring out the factor of management support. Management Support is one of the utmost extensively accepted condition for innovation adoption in any organization (Kumar, 1999). Added self-confidence and gratitude from top management helps to escalation the BIM adoption benefits (xu, 2014).

\subsection{Building Information Modeling (BIM) Knowledge Structure}

For execution of any novel technology all the allied knowledge is needed. As far as concerned about BIM, it is very exclusive domain in the AEC industry which is rising day by day (Succar, 2009). Knowledge about BIM should be identified in the BIM. The knowledge also protections the material characteristics, material specifications, Productivity, cost thresholds, time. Knowledge management principles should be joined into the BIM (Motawa, 2006). Change management plan should be incorporated in the BIM to deal changes i.e. addendum (Ding, 2015).

\subsection{Building Information Modeling (BIM) Technical Defects}

Numerous studies emphasized that there are possible flaws in BIM. Several studies have explained the potential technical defects of BIM. Individuals asked BIM software in hard form which has cost constraints (Olatunji, 2011). BIM is well-thought-out as an overhead by different business owners. The compatibility of BIM software with other software is also one of the major technical defects of BIM. Due to complexity of BIM software, problems are established in the operations.

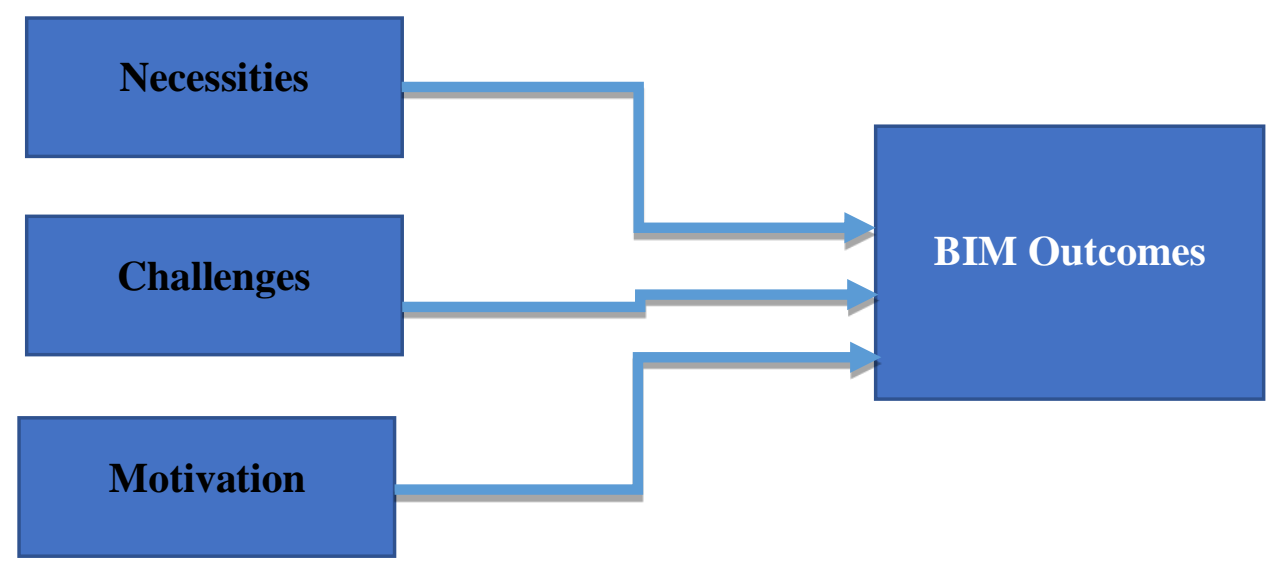

Figure 2: Conceptual Model

H1: Motivation has a positive effect on engineer's intention to adopt BIM for better 
outcomes?

H2: Challenges have a positive effect on engineer's intention to adopt BIM?

H3: The Necessities of other consultants will have positive effect on engineer's intention to adopt BIM?

\section{Research Method}

\subsection{Research Design and Sampling Method}

Quantitative research is used to collect and transform specific data that is used to evaluate. Quantitative research is the measurement of quantity. On the other hand qualitative research gives confidence to respondent to express his views more openly. Qualitative research is directly concerned with qualitative phenomenon (Kothari, 2004).

For present study quantitative approach has been used.

\subsection{Data Collection Method}

The following methods for the data collection were used; the selection of relevant method is dependent on the aim, objective of type of the research. Below few methods are given that was highlighted by Efron and Ravid (2013).

\subsection{Observation}

This tool was used in both type of researches qualitative and quantitative method. In qualitative method, it is used in the form of behavior logs, photographs, videos and audio recordings. in the quantitative method, it is used in the form of checklists, tally sheets and rating scales. In a general perspective observation is most suitable for quantitative research.

\subsection{Interviews}

This tool was used for qualitative research. Interviews were taken in the form of structured, semi structured, unstructured, focus groups and online interviews.

\subsection{Questionnaire Design}

The survey question was designed to check our research framework. The questionnaire consists of five sections: in first section the demographics of survey respondents while in the other sections questions related to all variables designed. The second, third, fourth and fifth section of the survey questionnaire engages the respondents to give their response against each question to degree to which they are agree or disagree (Batarseh, January 2018).

\section{Data Analysis/Results and Discussions}

Data was analyzed to answer the research question and hypothesis. An electronic and paper based survey comprising of five (05) sections was conducted to collect the data. Data retrieval was made after its execution.

a) Sample Profile

b) Reliability Analysis

c) Results and Discussions

All the engineers working in different organization in all over the Pakistan were targeted to get responses; however, 131 responses had been received out of total 166 architectures working as engineers in different organizations of Pakistan.

\begin{tabular}{|r|c|c|}
\hline \multicolumn{1}{|c|}{ Description } & Count/\%age \\
\hline 1 & Number of engineers for this research study. & 166 \\
\hline 2 & Number of engineers responded. & 131 \\
\hline 3 & Rate of Response. & $70 \%$ \\
\hline 4 & Total responses received (projects data). & 131 \\
\hline 5 & No. of discarded/ incomplete responses & 0 \\
\hline 6 & No. of final acceptable responses & 131 \\
\hline
\end{tabular}




\subsection{Sample Profile}

\subsubsection{Gender}

Following table shows the gender of the respondents who has taken interest in giving their responses for this study.

\begin{tabular}{|r|c|c|c|c|}
\hline & Frequency & Percent & Valid Percent & $\begin{array}{c}\text { Cumulative } \\
\text { Percent }\end{array}$ \\
\hline Male & 112 & 83.9 & 82.9 & 82.9 \\
Female & 19 & 15.1 & 15.1 & 100.0 \\
Total & 131 & 100.0 & 100.0 & \\
\hline
\end{tabular}

Respondent's professional experience shows that $27 \%$ of the respondents have less than 2 years of experience, while $55.8 \%$ have experience $2-5$ years, $7 \%$ have $6-10$ years and $11 \%$ of the population having experience more than 14 years of experience in engineering

\begin{tabular}{|c|c|c|c|c|}
\hline & Frequency & Percent & Valid Percent & Cumulative Percent \\
\hline$<2$ & 35 & 27.1 & 27.1 & 28.1 \\
$2-5$ & 78 & 58.8 & 58.8 & 85.9 \\
$6-10$ & 8 & 6.2 & 6.2 & 91.1 \\
$>14$ & 10 & 7.9 & 7.9 & 100.0 \\
Total & 131 & 100.0 & 100.0 & \\
\hline
\end{tabular}

\subsection{Building Information Modeling (BIM) Capability}

\subsubsection{In Academia, Education of BIM should be Necessary}

30 respondents out of 131 were strongly agreed that the education of BIM is very necessary in our curriculum to increase the BIM capability in the industry. More than 59\% of the respondents gave consent that the universities must include BIM in their curriculum. Table and graph shown below:

\begin{tabular}{|c|c|c|c|c|c|}
\hline & & Frequency & Percent & Valid Percent & $\begin{array}{c}\text { Cumulative } \\
\text { Percent }\end{array}$ \\
\hline \multirow{6}{*}{ Valid } & Strongly Agree & 31 & 21.2 & 21.2 & 21.2 \\
\hline & Agree & 45 & 36.6 & 36.6 & 57.8 \\
\hline & Neutral & 43 & 32.3 & 32.3 & 91.1 \\
\hline & Disagree & 11 & 9.1 & 9.1 & 99.3 \\
\hline & StronglyDisagree & 1 & .7 & .7 & 100.0 \\
\hline & Total & 131 & 100.0 & 100.0 & \\
\hline
\end{tabular}

\subsection{Motivation}

B1: Project team members are motivated to use new technologies for innovation $42 \%$ of the respondents confused whether they are motivated to use new technologies and to accept new challenges, they responded neutral response against this question which was quite surprising for me. On the other hard $52 \%$ of the respondents said that they and other team members are motivated to adopt new technologies for innovation and to find new trends. 


\begin{tabular}{|c|c|c|c|c|}
\hline & Frequency & Percent & Valid Percent & Cumulative Percent \\
\hline Strongly agree & 19 & 14.8 & 14.8 & 14.8 \\
Agree & 50 & 37.8 & 37.8 & 52.6 \\
Neutral & 57 & 43.0 & 43.0 & 95.6 \\
Disagree & 4 & 3.7 & 3.7 & 99.3 \\
Strongly Disagree & 1 & .7 & .7 & 100.0 \\
Total & 131 & 100.0 & 100.0 & \\
\hline
\end{tabular}

\subsection{BIM Outcomes}

D1: BIM Outcomes is progressing in engineering industry in Pakistan

\begin{tabular}{|c|c|c|c|c|c|}
\hline & & Frequency & Percent & Valid Percent & Cumulative Percent \\
\hline \multirow{6}{*}{ Valid } & Strongly agree & 19 & 17.0 & 17.0 & 17.0 \\
\hline & Agree & 53 & 37.8 & 37.8 & 54.8 \\
\hline & Neutral & 54 & 40.7 & 40.7 & 95.6 \\
\hline & Disagree & 4 & 3.7 & 3.7 & 99.3 \\
\hline & Strongly Disagree & 1 & .7 & .7 & 100.0 \\
\hline & Total & 131 & 100.0 & 100.0 & \\
\hline
\end{tabular}

D2: There is Key role of engineers in BIM Outcomes

\begin{tabular}{|c|c|c|c|c|c|}
\hline & & Frequency & Percent & Valid Percent & Cumulative Percent \\
\hline \multirow{6}{*}{ Valid } & Strongly agree & 32 & 24.4 & 24.4 & 24.4 \\
\hline & Agree & 60 & 45.2 & 45.2 & 69.6 \\
\hline & Neutral & 35 & 27.4 & 27.4 & 97.0 \\
\hline & Disagree & 3 & 2.2 & 2.2 & 99.3 \\
\hline & 11 & 1 & .7 & .7 & 100.0 \\
\hline & Total & 131 & 100.0 & 100.0 & \\
\hline
\end{tabular}

D3: Motivation is mandatory for BIM Outcomes

\begin{tabular}{|c|c|c|c|c|}
\hline & Frequency & Percent & Valid Percent & Cumulative Percent \\
\hline Strongly agree & 18 & 14.8 & 14.8 & 14.8 \\
Agree & 56 & 42.2 & 42.2 & 57.0 \\
Neutral & 48 & 36.3 & 36.3 & 93.3 \\
Disagree & 8 & 5.9 & 5.9 & 99.3 \\
Strongly & 1 & .7 & .7 & 100.0 \\
Disagree & 131 & 100.0 & 100.0 & \\
Total & & & \\
\hline
\end{tabular}


D4: BIM Outcomes is a tool that is helpful to increase the productivity

\begin{tabular}{|c|c|c|c|c|c|}
\hline & & Frequency & Percent & Valid Percent & Cumulative Percent \\
\hline \multirow{6}{*}{ Valid } & Strongly agree & 30 & 23.7 & 23.7 & 23.7 \\
\hline & Agree & 53 & 40.7 & 40.7 & 64.4 \\
\hline & Neutral & 35 & 25.9 & 25.9 & 90.4 \\
\hline & Disagree & 11 & 8.1 & 8.1 & 98.5 \\
\hline & Strongly Disagree & 2 & 1.5 & 1.5 & 100.0 \\
\hline & Total & 131 & 100.0 & 100.0 & \\
\hline
\end{tabular}

\section{Measurement Model}

\subsection{Reliability Testing}

In the initial phase of data analysis, we checked reliability and validity of all the constructs. Reliability is basically the internal consistency of the variables which is governed by the value of Cronbach's alpha. Cronbach's alpha value should be greater than 0.7 , the greater value of alpha shows that instrument is reliable which is going to be used for the study. Basically reliability is the fluency of an instrument in measuring the intended concepts. The value of Cronbach's alpha for all the variables used for our research given the range is between 0.74 and 0.875 which clearly shows that reliability within range and fit for use. Below mentioned is a systematic process flow of validation of the instruments to be used in the study:

\begin{tabular}{|c|c|}
\hline Variable & Cronbach's Alpha \\
\hline BIM Outcomes & 0.875 \\
\hline Necessities & 0.753 \\
\hline Challenges & 0.832 \\
\hline Motivation & 0.744 \\
\hline
\end{tabular}

The Cronbach's alpha values are shown below in histogram. Composite Reliability is another measure for internal consistency which is mostly used in social sciences. Ideally scenario the value of composite reliability ranges from 0.810 to 0.90 . In the current study the values are slighter high but within the acceptable threshold. The value of composite reliability is given below:

\begin{tabular}{|c|c|}
\hline Variable & Composite Reliability \\
\hline BIM Outcomes & 0.905 \\
\hline Necessities & 0.823 \\
\hline Challenges & 0.895 \\
\hline Motivation & 0.818 \\
\hline
\end{tabular}

\subsection{Validity Testing}

After performing reliability, the data were checked for validity. The Average Variance Extracted (AVE) has been checked to confirm the convergent validity. Convergent validity refers to how well the indicators of a construct load or converge on their respective constructs. The value of AVE should be greater than 0.50 in case of reflective constructs. In this study, the values of AVE for all the constructs are greater than 0.6 which depicts good convergent 
validity.The table for average variance extracted shown below:

\begin{tabular}{|c|c|}
\hline & Average Variance Extracted (AVE) \\
\hline BIM Outcomes & 0.914 \\
\hline Necessities & 0.643 \\
\hline Challenges & 0.676 \\
\hline Motivation & 0.803 \\
\hline
\end{tabular}

The value of rho $\mathrm{A}$ is given in below table:

\begin{tabular}{|c|c|}
\hline & rho_A \\
\hline BIM Outcomes & 0.911 \\
\hline Necessities & 0.823 \\
\hline Challenges & 0.875 \\
\hline Motivation & 0.841 \\
\hline
\end{tabular}

\section{Conclusion and Recommendations}

For the execution of BIM technology in AEC industry the acceptance and vast knowledge about BIM mechanism is very critical for BIM experts. For the achievement of the model on the key factors established from the data collected by different professional registered engineers throughout in Pakistan. After the examination of data, it clearly shows that three factor Necessities, Challenges and Motivation with management support has a positive impact on the BIM Outcomes in Pakistan. Furthermore, it is found statistically that "Necessities" is one of the significant factors for the Outcomes of BIM among the professional engineers in Pakistan. The sources of "Necessities" are education in the academic world, training in industry and skill enhancement.

The second statistically significant factor is "Motivation" which is the key factor for "BIM Outcomes" in the engineering industry in Pakistan. In a study conducted in china "Motivation" factor was not found statistically significant while other studies conducted in world showed that "Motivation" is one of the vital factors for "BIM Outcomes".

Moreover, "Motivation" will also increase the influence of "BIM Outcomes" among the engineers. Motivation is of two types one is related to project team and other one is related to clients, government and regulatory bodies. In earlier study by Z. Ding, "Motivation" was the most important factor for "BIM Outcomes" but in our study it is also the significant factor for "BIM Outcomes".

Overall if we see about the awareness of the BIM among the professionals to increase as compared to the previous study. Engineers are interested in the Outcomes of BIM. But in the AEC industry we are still lagging the progress as compared to other developing countries like India, Iraq, and Malaysia.

Almost all the respondents know about the basic of the BIM but miserably few of them were using the BIM in their respective organizations. The reason was the administration still considers it overhead as we studied in the literature that the payback period of this technology is pretty long and individuals do not want to diminish their profits from their business at instance.

Due to time and resource limitations, only one of the AEC professions was chosen as research respondents. For future study other professions like construction managers, project engineers, project managers etc should be selected to investigate the BIM Outcomes and issues in Pakistan. Moreover, the comparison can be done in the two professional like architects and civil engineers. This study conducted in the Pakistan as whole other studies can be done the zone 
wise or province wise to know about the exact status of "BIM Outcomes".

\section{References}

Alagarsamy, K., (2000). Building Information Modeling - A Quick Walk Through For Project Managers, Auburn University.

Adoption of Building Information Modelling. (2014). 50th ASC Annual International Conference Proceedings. Associated School of Construction.

Autodesk, (2003). Building Information Modeling. San Rafael, CA, Autodesk, Inc.

Ali, B. (2018). BIM Implementation in Public Sector of Pakistan Construction industry. ICCREM, 42.

Azhar. (2011). Building Information Modelling (BIM): Trends, benefits, risks and challenges for the AEC industry. Journal of ConstrutionEngineering and Management.

Azhar, S. (2008). " Building Information Modelling (BIM): A new paradigam for visual interactive modellling and simulation for construction projects".

Brewer, G., Gajendran, T., \& Goff, R., (2012). Building Information Modelling (BIM): an

Introduction and International Perspectives, The University of Newcastle.

Batarseh, S. (January 2018). Extrinsic and Intrinsic Drivers of BIM adoption in Construction Organizations.

Bazianic, V. (2004). Applying Information Modeling to Buildings.

Cunningham, G. (2015). BIM Implementation Developments for Architecture, Engineering and Construction (AEC) Organisations in the UK. School of Built Environment, Ulster University.

Dey, R., (2010). The History of the BIM and the Success Story Till Date, BIM: Building Information Modeling Blog. Retrieved on $8 / 6 / 13$ from

http://bim-modeling.blogspot.com/2010/12/history-of-bim-and-success-story-till.html.

Ding, Z. (2015). Key Factor for BIM adoption by Architects. emeraldinsight, 733.

Eastman. (2011). BIM Handbook. Wiley.

Eastman, C., Teicholz, P., Sacks, R., \& Liston, K. (2008). BIM Handbook: A Guide to Building Information Modeling for Owners, Managers,

Fatima. (2015). Adoption and Scope of BIm in construction industry of Pakistan. 6th International Conference on Structure Engineering and Construction Management, 90-99.

Fazli. (2014). Appraising effectiveness of Building Information Management (BIM) in Project Management. Procedia Technology, 1116-1125.

Haron, N. A. (n.d.). Implementation of Building Information Modelling (BIM) in Malaysia: A Review.

Hendrickson, C. \& Au, T., (2000). Project Management for Construction, Fundamental Concepts for Owners, Engineers, Architects and Builder,

Carnegie Mellon University, Pittsburgh, PA.

Hatem, W. A. (2018). Motivation Factor for Adopting BIM in Iraq. Engineering Technology and Applied Research, 2668.

Hergunsel, M. F. (2011). BENEFITS OF BUILDING INFORMATION MODELING.

Hong, Y. (2016). Factors influencing BIM Adoption in SM construction organization. ISARC.

Hussain, K. (2013). Building Information Modelling (BIM) Uses and Applications in Pakistan Construction Industry. 13th Conference on Construction applications of Virtual Reality. London, UK.

Ghosh, A. \& Chasey, A., (2013). Design Engineer Construct Integrated Management Lab: Leveraging Collaboration in the classroom with Virtual

J, L. (2007). BIM Handbook. New York: Wiley.

Kothari, C. (2004). Research Methodology. KOLKATA: New Age International Publishers.

Kumar, P. (1999). adoption of new information technologies in rural small businessess. Omega.

Kushwaha. (2016). Contribution of building information modelling (BIM) to solve problems in architecture, engineering and construction (AEC) industry and addressing barriers to implementation of BIM. International Research Journal of Engineering and Technology, 100-105.

Latiffi. (2013). Building information modelling (BIM) application in Malaysian construction Industry. International Journal of Construction Engineering and Management.

Lindlabad. (2013). Study of the implementation process of BIM in construction projects: Analysis of the barriers limiting BIM adoption in the AEC industry. 
Mankani, Z. (2009). Factors Influencing the Growth of BIM in Pakistan. Archi Times.

Masood, R. (2013). Is BIM Adoption Advantageous for Construction Industry of Pakistan? ELSEVEIR, 237.

Masood, R. (2014). Is BIM Adoption Advantageous for Construction Industry of Pakistan. ELSEVEIR, 238.

Mesároš, P. (2017). Exploitation and Benefits of BIM in Construction. IOP Conference Series: Materials Science and Engineering.

Motawa. (2006). "A knowledge-based BIM system for building maintenance". Automation in Construction, 173-182.

Mutai. (2009). "Factors influencing the use of building information modeling (BIM) within leading construction firms in the United States.

Nawari, N. (2012). "BIM Standard in Off-Site Construction.” Journal of Architectural Engineering, 18(2), 107-113

NIBS. (2007). National institute of Building Science, Whole Building Design Guide. US.

Olatunji. (2011). "Modelling the costs of corporate implementation of building information modelling". Journal of Financial Management of Property and Construction, 211-231.

Ozorhon. (2016). Critical Success factor for BIM Implementation. Journal of Management in Engineering, 33.

O'Brien, W., Soibelman, L., and Elvin, G. (2003). Collaborative design processes: An active- and reflective-learning course in multidisciplinary collaboration, Journal of Construction Education, 8(2), 78-93.

Papadonikolaki, E. (2017). Formal and informal relations within BIM-enabled supply chain partnerships. . Construction Management and Economics, 531.

Project Manager Education and Opinion, (2012). The language of project management, Published on July 17, 2012, Retrieved from http://projectmanager.com.au/blogs/language-project-management/

Qian, A. (2012). Benefits and ROI of BIM for Multi-Disciplinary Project Management. National University of Singapore. Retrieved on 8/19/13from http://www.icoste.org/wp-cont

RICS. (2014). State of BIM adoption and Outlook in India.

Sawhney. (2014). State of BIM adoption and outlook in India. RICS School of Built Environment, 1-32.

Succar. (2009). "Building information modelling framework: a research and delivery foundation for industry stakeholders. Automation in Construction, 357-375.

The U.S. Census Bureau. (2013). U.S. Census Bureau News, Department of Commerce, Retrieved on 8/21/2013 from http://www.census.gov/const/C30/release.pdf.

xu. (2014). Users oriented evaluation of building information model in the chinese construction industry. Automation in Construction.

Words \& Images, (2009). Building Information Modeling: Understanding and Operating in a New Paradigm, The Foundation of Wall and Ceiling Industry. Falls Church, VA 